\title{
Gender disparities in UK research publishing: Differences between fields, methods and topics
}

\author{
Mike Thelwall; Mahshid Abdoli; Anna Lebiedziewicz; Carol Bailey
}

How to cite this article:

Thelwall, Mike; Abdoli, Mahshid; Lebiedziewicz, Anna; Bailey, Carol (2020). "Gender disparities in UK research publishing: Differences between fields, methods and topics". Profesional de la información, v. 29, n. 4, e290415.

https://doi.org/10.3145/epi.2020.jul.15

Manuscript received on February $06^{\text {th }} 2020$ Accepted on June $05^{\text {th }} 2020$


Mike Thelwall $\square$

https://orcid.org/0000-0001-6065-205X

University of Wolverhampton

Statistical Cybermetrics Research Group

Wulfruna Street

Wolverhampton WV1 1LY, UK

m.thelwall@w/v.ac.uk

\section{Anna Lebiedziewicz \\ https://orcid.org/0000-0002-2606-7655 \\ University of Wolverhampton \\ Statistical Cybermetrics Research Group \\ Wulfruna Street \\ Wolverhampton WV1 1LY, UK \\ anna.l@wlv.ac.uk}



Mahshid Abdoli

https://orcid.org/0000-0001-9251-5391

University of Wolverhampton

Statistical Cybermetrics Research Group

Wulfruna Street

Wolverhampton WV1 1LY, UK

m.abdoli@w/v.ac.uk

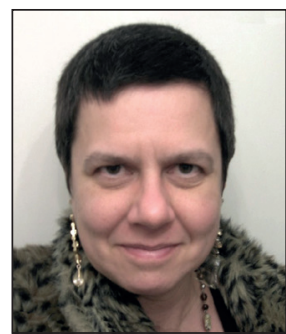

Carol Bailey

https://orcid.org/0000-0002-2734-4060

University of Wolverhampton

Statistical Cybermetrics Research Group

Wulfruna Street

Wolverhampton WV1 1LY, UK

c.bailey@w/v.ac.uk

\begin{abstract}
Gender disparities persist in UK research, with female minorities in most science, technology, engineering and mathematics (STEM) subjects but female majorities in others. The nature of the gender disparity differences between subjects needs to be understood if effective remedial actions are to be targeted at STEM subjects suffering from a lack of women, in contrast to other subjects without shortages. Evidence from the USA suggests that women engage more in people-related subjects, qualitative methods, veterinary science and cell biology and men engage more in thing-related subjects, power/control fields, patient-related research, abstraction and quantitative methods, except surveys. This article investigates gender disparity differences in UK first authorship for journal articles in nearly all of science split into 26 broad and 308 narrow Scopus fields. The results largely replicate the USA but suggest that more life science topics may be female-associated in the UK and patient-related research might not be male-associated. UK STEM gender parity initiatives might therefore emphasise people-oriented, and perhaps socially positive, aspects of currently masculine STEM topics and approaches (e.g., abstraction, mathematical quantitative methods), and promote female-friendly topics, methods and goals within male-dominated fields in addition to tacking implicit and explicit sexism and providing a supportive working environment.
\end{abstract}

\section{Keywords}

Gender inequalities; Gender gaps; Scientific publishing; Disciplinary differences; Careers; Academic careers; Gender. 


\section{Introduction}

Female academics are rare in many UK STEM fields, according to HESA data (see below). The female STEM minority is a common -but not universal- international problem, whether due to explicit discrimination, implicit discrimination, socially constrained choices, or individual preference. Other subjects with large UK gender disparities include economics (28\% female UK academic staff in 2016) (Tenreyro, 2017), biological sciences (61\% female postgraduates in 2011-12: Society of Biology, 2013) and nursing (probably $90 \%+$ female, see below; also $94 \%$ female in the USA: Mott \& Lee, 2018).

The reasons why gender disparities vary greatly between fields within UK academia are poorly understood

The reasons why gender disparities vary greatly between fields within UK academia are poorly understood. This undermines attempts to assess whether current initiatives, such as Athena SWAN, promote optimal strategies for increasing female participation and career progression in STEM (e.g., Armstrong; Jovanovic, 2017; Lipton, 2017).

http://www.ecu.ac.uk/equality-charters/athena-swan

The following theories have been proposed to explain current field differences in gender disparities, and the lack of women in STEM subjects in some countries, in terms of constraints on female career choices:

1) Biological sex differences in abilities.

Although there may be marginal differences in some relatively minor abilities (Hines, 2011; Rippon, 2019), these are insufficient to account for large differences between fields.

2) Socialised gender differences in capabilities.

Although girls outperform boys in science tests in most countries, with the gap being largest in countries with the greatest gender inequality (Stoet; Geary, 2018), there is evidence of childhood social factors leading to gender capability differences in favour of boys for STEM in the USA. For example, whilst younger girls in the USA are equally capable as boys at computing, older girls fall behind after choosing to take fewer optional computing classes (Cheryan; Ziegler; Montoya; Jiang, 2017). Less early experience of physics and engineering may also explain lower average female capability in these fields in the USA (Cheryan; Ziegler; Montoya; Jiang, 2017). Gender differences in beliefs about capability can lead to differing interests (Shapiro; Williams, 2012) and career choices (e.g., Tellhed; Bäckström; Björklund, 2017), therefore translating into later life capability differences.

3) Gender conformity.

From a sociological perspective, identifying as male or female rather than non-binary means tending to choose behaviours and activities associated with that gender (e.g., clothes, fiction reading, hobbies) even though everyone engages in some activities typical of another gender (e.g., cross-dressing, men reading chick-lit, women boxing) (Lindsey, 2016). In this context, academic fields (or careers) that are believed to be gender-imbalanced would be gender non-conforming for one gender. Gender conformity pressure can be powerful (Gordon; Krieger; Okechukwu et al., 2017) but it is not known whether this is a strong career choice motivation in the UK since gender non-conformity is increasingly accepted (BSA, 2018). Female role models have been proposed as a partial solution to this, but evidence for their efficacy is mixed (Cheryan; Drury; Vichayapai, 2013; Cheryan; Siy; Vichayapai; Drury; Kim, 2011; Young; Rudman; Buettner; McLean, 2013). For example, the perception of nursing as suitable for UK women has been attributed to nurse and statistician Florence Nightingale (Christensen, 2017), but statistics remains male-dominated. Gender role assumptions in society and within education also probably restrict career choices (Robnett, 2016).

4) Explicit discrimination by gender or biological sex at key career stages (e.g., recruitment, tenure).

Recruiters may make assumptions about the capabilities of candidates based on their gender (e.g., Moss-Racusin; Dovidio; Brescoll; Graham; Handelsman, 2012; Reuben; Sapienza; Zingales, 2014), although a large-scale US study suggests an overall 2:1

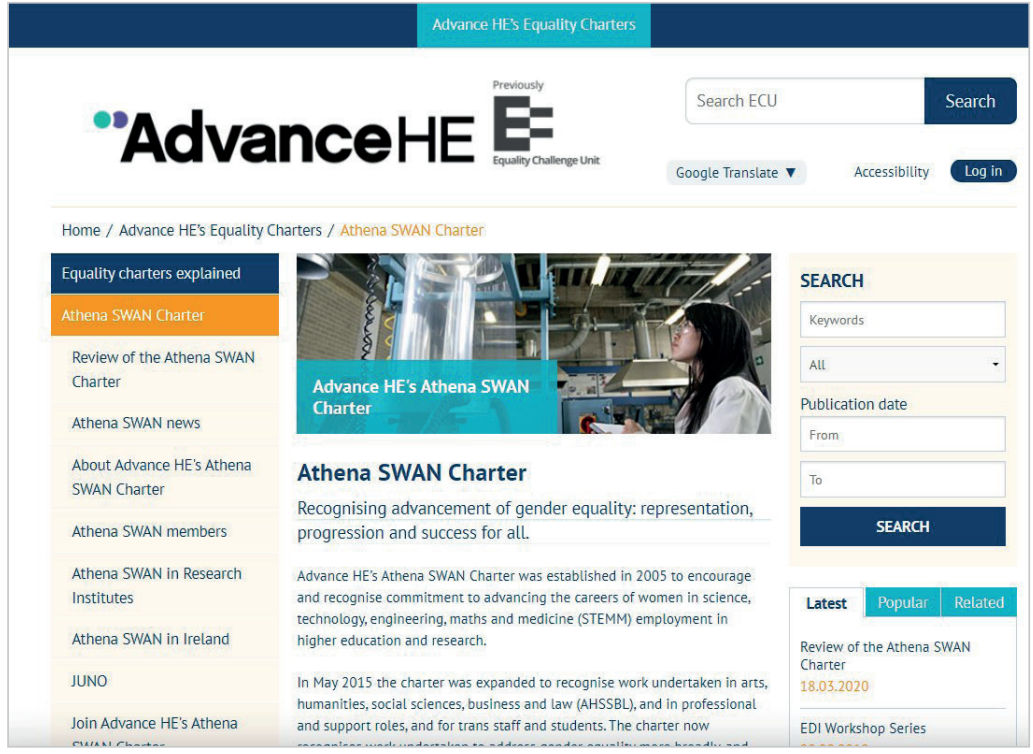

http://www.ecu.ac.uk/equality-charters/athena-swan 
preference for female tenure track applicants across almost all academic fields (Williams; Ceci, 2015). Male-dominated appointment and promotion committees may have a greater affinity with similar men (Van-den-Brink; Benschop, 2012), perpetuating existing gender disparities. Some STEM fields may have generated chilly climates for female researchers (Stockard; Greene; Richmond; Lewis, 2018). More subtly, highly successful US male biologists have been found to train fewer women than the sector average in biology, although this could be due to self-selection bias (Sheltzer; Smith, 2014).

5) Implicit discrimination within careers by gender or biological sex.

Failure to account for the greater average responsibility of women in informal carer roles (Dahlberg; Demack; Bambra, 2007; ONS, 2013) and time off for childbirth or childcare in promotion or tenure are important examples of implicit discrimination that can disproportionately harm women's career prospects (e.g., Brown; Watson, 2010; England, 2010). Women may also be discouraged when in minority (e.g., Main, 2018).

Personal choice may also be a factor in gender disparity differences between fields, and the unpopularity of STEM amongst US/UK women. One puzzling US study found a much greater tendency for US women to leave (academic and non-academic) STEM careers for non-STEM careers (50\% professional) compared to women in non-STEM professional careers. The study found that higher salary, training, and job satisfaction did not lead to greater STEM retention (Glass; Sassler; Levitte; Michelmore, 2013). This suggests that STEM-specific factors are relatively subtle and difficult to quantify, so personal choice may be a key factor.

Two theories emphasise female choice as a determinant of participation rate differences between fields.

1) Biological sex differences in preferences.

There is some evidence of a sex-related genetic component to interests. For example, some toys are preferred by boys or girls before they learn gender differences, a gender difference that is mimicked in some non-human primates (Hines, 2011). This may transfer into later career choices to some extent (Su; Rounds; Armstrong, 2009).

2) Socialised gender differences in career goals.

Women in the USA have been shown to be more likely to have communal goals for their career, such as generating a social impact or having time for family life, whereas men are more likely to want status (agentic goals) (Diekman; Steinberg, 2013). These goals are presumably socialised. They overlap with the people/thing preferences discussed above in terms of career preferences, since working with people often leads to socially positive outcomes (Yang; Barth, 2015). Family preferences do not seem to affect whether a STEM qualified female chooses a STEM career, although men choosing STEM are more likely to expect to be childless (Sassler; Glass; Levitte; Michelmore, 2017).

Overall, evidence mostly from the USA suggests that the most direct reason for the differing female participation rates in STEM and other subjects is that women have different subject preferences to men (Ceci; Williams, 2011), whatever the fundamental causes of those preferences. Thus, it is important to understand why some academic subjects are relatively unattractive to women.

This study assesses field differences in gender disparities in UK research publishing to give finer grained insights than available from national statistics. The focus is on research publishing rather than research employment for three reasons:

- whilst academic employment statistics are available for the UK (see below), available classifications of research publications are finer grained;

- publication metadata can give even finer-grained and different insights into research interests; and

- the results are internationally comparable, whereas employment statistics are not, and are not always collected or published.

A secondary goal is to assess differences with the USA (from a previous similar study: Thelwall; Bailey; Tobin; Bradshaw, 2019) because these may illuminate underlying factors contributing to different outcomes in the two countries. Although local context has a substantial influence on gender imbalances in science (Etzkowitz;

Kemelgor; Uzzi, 2000) and the UK and USA organise higher education differently, they share a common primary language and aspects of culture. The people/things theory is used to guide the analysis rather than the communal/agentic goals theory because the latter is impractical to apply to fields. Any failure of this theory to explain the results suggests that other theories (e.g., communal/agentic or hypotheses from the first set above) may be needed instead or in addition. The research questions are as follows.

RQ1: How do author gender disparities vary between broad and narrow fields for UK journal articles? Are there differences from the USA?

RQ2: How do author gender disparities vary between topics, methods and styles for UK journal articles? Are there differences from the USA? 


\section{Background}

There are large international differences in social expectations about the types of jobs that are suitable for women for historical reasons (e.g., Alesina; Giuliano; Nunn, 2013). An analysis of 115 field categories from arXiv and PubMed found substantial differences in the proportions of female authors between fields and countries, with the UK being about average on a world scale (Holman; Stuart-Fox; Hauser, 2018). Contrasting greatly with the UK, women have dominated Malaysian academic computer science at all levels (Othman; Latih, 2006). Over a decade ago, women dominated undergraduate education in Iran in all areas except engineering, despite previous (and ongoing) government attempts to block women from "masculine" academic subjects in prestigious universities (Haeri, 2013; Mehran, 2009; Shavarini, 2005). In the EU, women form the majority of scientists and engineers in Lithuania, Bulgaria, Latvia, Portugal and Denmark (Eurostat, 2019). This section focuses on the USA and UK, however, as the primary comparison in the current paper.

The UK and USA organise academia differently. In the UK, most universities are public whereas equivalent US degrees take longer and there are many private and state funded universities. Salaries for UK academics below (full) professor level are relatively standardised, with nationally agreed pay scales. Career-long publishing is necessary for periodic research assessments (www.ref.ac.uk) and usually for promotion. In the US, academics typically start as an assistant professor and apply for tenure after about seven years, needing to provide evidence of research achievements. Ongoing publishing in both countries would presumably help subsequent promotion and other career prospects and may be encouraged at university level to enhance prestige or the positions in university or department rankings (e.g., U.S. News department rankings for the USA or international university league tables for both countries). Contracts in the USA are typically for 9 months per year, with faculty often applying for research funding grants or extra summer teaching to cover the remaining three months. The lack of standardised US pay scales means that academics in higher status fields like law, economics and engineering are paid more in some institutions (US Department of Labor, 2019; Watson, 2019), further enhancing their status. Failure to get US tenure may lead to academics moving to a different institution or joining a teaching-focused two-year college. Because of the different organisations of the university systems, gender may influence academic careers and publishing differently in each country. Other factors, such as universities in relatively isolated campuses in the USA may also influence the career prospects of researchers in relationships if the career of one partner is prioritised: this problem is recognised through support for dual career couples:

http://www.hercjobs.org/dual-careers

\subsection{People/things or communal/agentic goals in the USA and exceptions}

As mentioned in the introduction, women in the USA are more likely to be found in people-oriented rather than thing-oriented careers (Su; Rounds; Armstrong, 2009; Su; Rounds, 2015). Social and family impact (communal goals) tend to be more important career goals for US women in comparison to personal status (agentic goals) for US men (Diekman; Brown; Johnston; Clark, 2010; Diekman; Steinberg; Brown; Belanger; Clark, 2017; Diekman; Steinberg, 2013). This largely overlaps with the people/thing hypothesis because social impact fields are likely to involve people. Although the communal/agentic theory has more direct evidence in the sense of matching what people claim their career goals are, the current article focuses on the people/thing hypothesis because this aligns better with the methods used. It aligns better because it is relatively straightforward to check whether a description of a research topic aligns with people or things (or neither). In contrast, the communal/agentic goals theory is more about perceptions and it is problematic to infer whether a topic would be studied because researchers perceived that it would support their communal or agentic goals.

One previous study has examined the people/things hypothesis for research publishing in the USA, comparing the proportion of female first authored articles within broad and narrow Scopus categories and detecting gendered terms used in article titles, keywords and abstracts for articles published in 2017 (Thelwall; Bailey; Tobin; Bradshaw, 2019). The results were broadly consistent with the people/things hypothesis in the sense that people-related fields tended to have higher proportions of female first authors and thing-related fields tended to have higher proportions of male first authors. This extended to methods, with women being more likely to use qualitative methods and men be-



Maximize your dual career job search with HERC

HERC is invested in the success of dual career couples, as the outcomes of a dual career job search can directly affect employee
success ond quality of life. HERC supports dual career couples as a matter of intersectional and gender equity, since dual caree

http://www.hercjobs.org/dual-careers 
ing more likely to use quantitative methods. A female tendency to use qualitative methods, relative to males, and a corresponding male tendency to use quantitative methods has also been found in many international studies of individual fields (e.g., Nunkoo; Thelwall; Ladsawut; Goolaup, 2020; Williams; Kolek; Saunders; Remaly; Wells, 2018). There were important exceptions in the USA study, however. Relatively high female interest in veterinary science and cell biology could not easily be explained by their topics due to the absence of people, although they might both offer social impact goals. Similarly, there was relatively high male interest in research involving patients (i.e., people) and abstraction (e.g., pure maths, logic), despite the absence of a focus on things. Men were also more interested in people-related fields involving power or control, including law and politics, perhaps because they fulfil status goals (Diekman; Steinberg, 2013). Thus, in academia, the people/things hypothesis fits the USA to a large extent, with important exceptions that seem to fit the communal/agentic goals theory.

A study of India with similar methods also found broad agreement with the people/things hypothesis but substantial differences from the USA, such as veterinary science being the most male field, women forming a lower proportion overall, and narrower differences in gender proportions between fields (Thelwall; Bailey; Makita; Sud; Madalli, 2019).

\subsection{UK context}

The people/things and communal/agentic hypotheses have not been tested in the UK but people/things can be checked against public statistics about course enrolments and academic staff. According to the relatively broad categories reported by the UK Higher Education Statistics Agency (HESA), in 2016/7, a minority of UK postgraduate degrees were awarded to women in science $(44 \%)$ but a majority (52\%) in non-science subject areas (HESA, 2018a). Whilst women were less likely to complete a research degree in most STEM fields, gaining only a quarter of qualifications in Engineering \& Technology and Computer Science, they were a majority in the Biological Sciences (Table 1). Largely people-oriented subject areas (Education, Languages, Subjects Allied to Medicine, Social Sciences) mostly have substantial female majorities, and largely thing-based fields (Physical Sciences, Engineering \& Technology, Computer Science) have substantial male majorities. In comparison, $58 \%$ of all UK degrees were awarded to women, with female to male (F/M) ratios varying from 3.73 (Subjects Allied to Medicine) to 0.23 (Engineering \& Technology).

Gender proportions in postgraduate degrees do not necessarily translate into similar gender proportions in academia because of historical factors (e.g., there are more female students now than 20 years ago, when some current staff were recruited) and career choices (e.g., a higher proportion of postgraduate female mathematicians may prefer maths teaching than maths research).

Although women in the UK receive $57 \%$ of undergraduate degrees and $47 \%$ of postgraduate research degrees (HESA, 2018b: Table K), there are fewer female academics (44\%), full professors (25\%) (HESA, 2018b: Table B), and university governing board members (32\%) (Sherer; Zakaria, 2018). Lower proportions of women at senior academic levels may be partly due to historically higher gender inequalities and greater female ambivalence about status goals, with men tending to garner higher prestige indicators (Kandiko-Howson; Coate; De-St-Croix, 2018). As mentioned above, low proportions of women in senior positions could also be partly due to implicit bias, such as by predominantly male senior promotion committees more valuing male gendered achievements. Women were more likely to have a primarily teaching role than to conduct teaching and research, with $52 \%$ of academics on teaching-only contracts being female, $41 \%$ on teaching and research contracts and $47 \%$ (i.e. the sector average) on research-only contracts (HESA, 2018b: Table B). This would be consistent with a mid-career choice for women to temporarily or permanently switch to a teaching-only role (perhaps related to child-care responsibilities).

Some women may accept temporary teaching only roles in the hope of longer-term permanence and more time for research (Dyer; Walkington; Williams; Morton; Wyse, 2016). As

Table 1. Research-based postgraduate degree awards in the UK 2016/7 (e.g., PhD, MPhil) in descending order of female proportion*

\begin{tabular}{|l|r|r|l|}
\hline \multicolumn{1}{|c|}{ Subject area } & Students & Female & F/M \\
\hline Veterinary Science & 85 & $71 \%$ & 2.40 \\
\hline Education & 1,045 & $68 \%$ & 2.12 \\
\hline Languages & 1,620 & $62 \%$ & 1.61 \\
\hline Biological Sciences & 3,935 & $61 \%$ & 1.59 \\
\hline Subjects Allied to Medicine & 1,985 & $58 \%$ & 1.40 \\
\hline Medicine \& Dentistry & 2,455 & $56 \%$ & 1.28 \\
\hline Mass Communications \& Documentation & 250 & $56 \%$ & 1.27 \\
\hline Agriculture \& Related Subjects & 225 & $56 \%$ & 1.25 \\
\hline Creative Arts \& Design & 880 & $52 \%$ & 1.10 \\
\hline Social Studies & 2,385 & $50 \%$ & 1.02 \\
\hline Law & 520 & $45 \%$ & 0.82 \\
\hline Historical \& Philosophical Studies & 1,990 & $44 \%$ & 0.80 \\
\hline Business \& Administrative Studies & 1,280 & $44 \%$ & 0.78 \\
\hline Architecture, Building \& Planning & 455 & $42 \%$ & 0.70 \\
\hline Physical Sciences & 3,515 & $36 \%$ & 0.56 \\
\hline Mathematical Sciences & 735 & $27 \%$ & 0.37 \\
\hline Computer Science & 1,105 & $25 \%$ & 0.34 \\
\hline Engineering \& Technology & 28,155 & $47 \%$ & 0.88 \\
\hline Total (incl. combined) & & $25 \%$ & 0.33 \\
\hline Sor & & & \\
\hline
\end{tabular}

*Source: HESA, 2018c: Figure 18. 
part of this, they may produce lower quality research with their limited scholarship time to stay in contact with their field. Probably because of a greater share of teaching-only contracts, women may write fewer journal articles than men (for UK social science: Schucan-Bird, 2011), reducing their longterm research career prospects.

Although the classification systems are different, there are some differences in gender proportions between research-based postgraduate degree awards (Table 1) and academic staff (Table 2) for Veterinary Science $(71 \%$ female postgraduate awards vs. $54 \%$ female staff) and Law (45\% vs. $52 \%$ ), despite broad overall similarity. Differences could be due to gender balance changes over time, gender differences in the pipeline between research degrees and academic jobs, or classification anomalies (academic staff may be classified by department rather than by specialism, such as subject specialists within education departments).

As mentioned above, gender disparities in employment do not necessarily translate directly into gender disparities in publishing, as measured in the current article (whether in the UK or USA). Whilst many previous studies have found men to publish more journal articles (Nielsen, 2016; Rørstad; Aksnes, 2015; Van-Arensbergen; Van-der-Weijden; Van-den-Besselaar, 2012), this seems to be due to job type differences, such as more women working part time and in teaching-focused jobs (Ceci; Ginther; Kahn; Williams, 2014), rather than differences between genders within comparable jobs. For example, gender disparities in productivity for ecology researchers disappear after factoring out career breaks and self-citations (Cameron; White; Gray, 2016).

\subsection{Recent UK academic gender in- equality research}

According to the United Nations Development Programme (UNDP), the UK (rank 28 out of 188 in the world) had less gender inequality than the USA (rank 48), partly due to a slightly higher proportion of women in employment (F: $56.9 \%$; M: $68.7 \%$ in the UK; F: $56.0 \%$; M: $68.4 \%$ in the USA) (UNDP, 2016). There do not seem to have been any claims about causes of gender inequalities in academia that are UK-specific (there are many for the USA: Thelwall; Bailey; Tobin; Bradshaw, 2019) or that apply to the UK but not the USA. Recent UK-specific academic gender inequalities research has focused instead on the steps necessary to promote successful female careers in STEM subjects or overall.
Table 2. Full-time and part-time academic staff in the UK $2016 / 7$ by HESA cost centre, in descending order of female proportion*

\begin{tabular}{|c|c|c|c|}
\hline HESA cost centre & Total** & Female & $\mathbf{F} / \mathbf{M}$ \\
\hline Nursing \& Allied Health Professions & 10,030 & $75 \%$ & 2.99 \\
\hline Education & 8,990 & $67 \%$ & 2.02 \\
\hline Modern Languages & 5,865 & $66 \%$ & 1.93 \\
\hline Health \& Community Studies & 2,980 & $65 \%$ & 1.90 \\
\hline Social Work \& Social Policy & 2,895 & $65 \%$ & 1.82 \\
\hline Psychology \& Behavioural Sciences & 6,955 & $61 \%$ & 1.55 \\
\hline Continuing Education & 930 & $60 \%$ & 1.48 \\
\hline English Language \& Literature & 4,890 & $56 \%$ & 1.29 \\
\hline Sociology & 3,145 & $55 \%$ & 1.23 \\
\hline Catering \& Hospitality Management & 655 & $54 \%$ & 1.16 \\
\hline Veterinary Science & 1,390 & $54 \%$ & 1.16 \\
\hline Clinical Medicine & 24,305 & $53 \%$ & 1.15 \\
\hline Law & 5,660 & $52 \%$ & 1.07 \\
\hline Art \& Design & 10,375 & $51 \%$ & 1.06 \\
\hline Anthropology \& Development Studies & 920 & $51 \%$ & 1.04 \\
\hline Anatomy \& Physiology & 1,865 & $50 \%$ & 1.02 \\
\hline Pharmacy \& Pharmacology & 2,325 & $50 \%$ & 1.00 \\
\hline Classics & 650 & $49 \%$ & 0.96 \\
\hline Agriculture, Forestry \& Food Science & 1,145 & $49 \%$ & 0.95 \\
\hline Clinical Dentistry & 1,535 & $47 \%$ & 0.88 \\
\hline Biosciences & 13,965 & $46 \%$ & 0.84 \\
\hline Area Studies & 375 & $45 \%$ & 0.83 \\
\hline Archaeology & 775 & $45 \%$ & 0.80 \\
\hline Music, Dance, Drama \& Performing Arts & 7,855 & $43 \%$ & 0.76 \\
\hline Business \& Management Studies & 15,455 & $43 \%$ & 0.74 \\
\hline History & 3,520 & $42 \%$ & 0.71 \\
\hline Media Studies & 4,670 & $41 \%$ & 0.70 \\
\hline Geography \& Environmental Studies & 2,395 & $39 \%$ & 0.65 \\
\hline Politics \& International Studies & 3,385 & $37 \%$ & 0.59 \\
\hline Theology \& Religious Studies & 715 & $37 \%$ & 0.58 \\
\hline Sports Science \& Leisure Studies & 2,875 & $36 \%$ & 0.57 \\
\hline Earth, Marine \& Environmental Sciences & 3,675 & $35 \%$ & 0.53 \\
\hline Architecture, Built Environment \& Planning & 4,065 & $34 \%$ & 0.52 \\
\hline Economics \& Econometrics & 2,970 & $30 \%$ & 0.42 \\
\hline Philosophy & 1,115 & $30 \%$ & 0.42 \\
\hline Chemistry & 4,310 & $29 \%$ & 0.41 \\
\hline Chemical Engineering & 1,225 & $26 \%$ & 0.35 \\
\hline Mineral, Metallurgy \& Materials Engineering & 1,200 & $26 \%$ & 0.34 \\
\hline Mathematics & 4,690 & $23 \%$ & 0.31 \\
\hline Civil Engineering & 1,985 & $23 \%$ & 0.30 \\
\hline $\begin{array}{l}\text { IT, Systems Sciences \& Computer Software } \\
\text { Engineering }\end{array}$ & 6,875 & $22 \%$ & 0.29 \\
\hline General Engineering & 3,805 & $22 \%$ & 0.28 \\
\hline Physics & 5,175 & $19 \%$ & 0.23 \\
\hline Mechanical, Aero \& Production Engineering & 5,135 & $17 \%$ & 0.21 \\
\hline Electrical, Electronic \& Computer Engineering & 4,380 & $15 \%$ & 0.17 \\
\hline Total & 204,095 & $46 \%$ & 0.84 \\
\hline
\end{tabular}

*Source: HESA, 2018d: second chart

**The counts are of full-person equivalents, which is like the standard full-time equivalent calculation but excludes time working in unrelated roles. 
Conflicting opinions from interviews with 55 staff members from one UK medical school suggested that the most important interventions needed were for childcare, career progression, general, or financial/strategic policy initiatives (Bryant; Burkinshaw; House; West; Ward, 2017). Failure to provide support at key stages of careers may have a long-lasting effect (Maddrell; Strauss; Thomas; Wyse, 2016).

Athena SWAN is the main UK higher education initiative to tackle gender inequality, comparable in goals to Advance in the USA, which uses a grant-based strategy (Rosser; Barnard; Carnes; Munir, 2019). UK institutions can apply for certification that they are compliant with the goals, ultimately leading to a Gold Award for "beacons of achievement in gender equality" (Barnard, 2017), and require at least a Silver Award to apply for one source of funding (Rosser; Barnard; Carnes; Munir, 2019). It seems to be contributing to an overall more positive culture of willingness to address gender inequalities in the UK (Maddrell; Strauss; Thomas; Wyse, 2016). Nevertheless, the amount of time taken on work to achieve the benchmarks for awards may be detrimental to the long-term careers of individual (mainly female) researchers and the programme cannot tackle wider societal issues (Caffrey; Wyatt; Fudge; Mattingley; Williamson; McKevitt, 2016; Ovseiko; Chapple; Edmunds; Ziebland, 2017). Promoting gender inequality without Athena SWAN can also be time-consuming, especially if not in a supportive environment (Wright; Cooper; Luff, 2017).

Probably because of the complexity of the issue, no research has demonstrated the case-and-effect impact of Athena SWAN on female careers, although there are clear university policy changes and strategies to track progress (Rosser; Barnard; Carnes; Munir, 2019). Whilst Athena SWAN awards require concrete evidence of progress, a survey of UK medical schools with Silver Awards found that Silver Award status had not improved female researcher careers (GregorySmith, 2018). The head of an Athena SWAN Gold Award chemistry department has argued that progress can be made through a combination of pro-active actions, such as searching for suitable female applicants, and continual small steps that improve the working lives of all staff (Welton, 2016).

\section{Methods}

\subsection{Research design}

This article focuses on research publishing as a window to gain insights into gender disparity differences between fields. The research design was (RQ1) to assess the proportion of female first authors in broad and narrow fields to identify field differences in gender disparities and (RQ2) to use word association analyses to identify gender disparities in research topics, methods or styles. Scopus was used in preference to the Web of Science for its narrower subject categories:

334 Scopus categories listed at:

https://www.elsevier.com/solutions/scopus/how-scopus-works/content

compared to 153 WoS categories listed at:

https://images.webofknowledge.com/images/help/WOS/hp_research_areas_easca.html

And for compatibility with a previous study of the USA.

The gender of the first author was used because in all broad fields the first author contributes most to the research (Larivière; Desrochers; Macaluso; Mongeon; Paul-Hus; Sugimoto, 2016). Ignoring all author genders after the first is a simplifying assumption that serves to reduce gender biases by a small amount. For example, the assumption is always correct for solo research and for research where all authors have the same gender. It is only incorrect when an article has multiple authors of mixed genders, and an author after the first with a different gender has had a substantial input. Alphabetical author lists have a very small impact on some fields in practice (see below). Biological fields with influential last authors are more problematic because a senior male last author may have often designed and funded a study carried out by a junior female author, causing a systematic bias. In this case, the junior female would have at least chosen the narrow topic and lab for her research (e.g., PhD) and agreed to the individual study even if she had not selected or designed it. Non-binary genders are ignored because they cannot be detected from first names and there are too few to give useful information with the statistical approach used here. For the same reason, research is characterised as from the UK if the first author has a UK affiliation, irrespective of their nationality and the affiliations and nationalities of any other authors.

For RQ1, simple authorship gender proportions were calculated for each broad and narrow Scopus field.

For RQ2, the terms used in article titles, keywords and abstracts were combined and compared between male first-authored and female first-authored UK journal articles, both within and across narrow fields. Terms with statistically significant gender differences were then assessed for indications of topics, methods and styles. This is an indirect and non-comprehensive way of addressing RQ2 but is a practical method for getting insights into gender disparities across academia.

\subsection{Data}

The basic dataset consisted of records for all documents of type journal article in Scopus (excluding reviews, letters, editorials etc.) that were published in 2017 and had a first author with a UK affiliation and a first name from which a gender could be inferred with high accuracy. The year 2017 was chosen to give the most recent available complete year. 
The records were downloaded from Scopus in February 2018, over a month after the end of 2017, and so should be reasonably complete. Queries of the form:

\section{SUBJMAIN(1105) AND DOCTYPE(ar) AND SRCTYPE(j) AND AFFILCOUNTRY(“United Kingdom”)}

were used for each of the 308 Scopus narrow fields (excluding the 26 overlapping broad field categories 1100 to 3600 , but including 1000 Multidisciplinary) (Scopus, 2018: the AJSC tab of the Source title list spreadsheet). In the illustrative query above, 1105 is the field code for Ecology, Evolution, Behavior and Systematics. Scopus returns a maximum of 5,000 articles per query and so the queries for each field with over 5,000 articles were repeated in reverse sorting order to download an additional (up to) 5,000 matches, when necessary. This resulted in a complete set of records for all fields. Records where the first author did not have a UK affiliation were removed, leaving 142,636 Scopus journal articles from 2017 with a UK-affiliated first author.

Each article was assigned to one or more narrow fields, when it was returned for the query for that narrow field. These narrow fields are the standard Scopus journal-level categories. Scopus assigns journals to all categories where they fit well, but can sometimes also assign them to apparently inappropriate categories (Wang; Waltman, 2016). This creates the risk that some of the findings are caused by Scopus classification anomalies rather than gender disparities. Such instances are flagged, in the text when identified.

Each article was assigned to one or more broad fields containing the narrow fields of the article, again using the Scopus journal classifications.

Each article was attributed a first author gender or, if no gender could be found, the article was discarded. Author gender was inferred using a look-up table of 1,021 male names and 3,937 female names, culled from the USA 1990 census and only including names that are used at least $90 \%$ of the time by the same gender. This matched $65 \%$ of the UK first author records (92,058 articles). A further $14 \%$ of UK first authors used initials, leaving $21 \%$ using unclassified first names. The USA census was chosen since the UK has no similar source. Gender APIs were not used (although they would have increased the number of gendered papers by about $8 \%$, if using records that were at least $90 \%$ monogender based on at least 100 social media profiles) because they are not transparent and exploit genders declared in social media profiles, which are less reliable than census data. The most common ungendered names were Alex (339 articles), Nicola (302), Robin (213), Jamie (212), Sam (196), Ali (179), Jan (164), Wei (140), Lee (137), and Konstantinos (127). Of these, only Konstantinos is monogender (male, as shown by Googling, konstantinos site:ac.uk). Nicola is mainly female in the UK but male for Italian researchers in the UK (Google, nicola site:ac.uk), and Ali is a mainly male name but an occasional short form of Alison and Alicia (Google, ali site:ac.uk).

\subsection{Alphabetisation checks}

The assumption that the first author gender is the main author gender may be violated when article authors are listed alphabetically. The extent of alphabetisation of each narrow field was estimated by comparing the level of alphabetisation with that expected by chance. First author gender errors due to alphabetisation were rare overall (2\%), but most prevalent (for a field with $>50$ articles) in Discrete Mathematics and Combinatorics (12\%). Male-to-female and female-to-male errors largely cancel out, however, leaving a maximum net difference of $2 \%$ for any field. Thus, the proportions of authors of each gender in a field are largely unaffected by alphabetisation. The statistical power of the word association tests for some individual fields is weakened by the occasional swapping of first author genders, however, but this cannot cause false positive results.

\subsection{Gender detection accuracy checks}

The gender detection heuristic is not always correct. To its accuracy, a set of 1,000 UK first authored articles from 2017 was selected from the entire dataset (before removing ungendered articles) with a random number generator and their first authors classified for gender, when possible, by searching for their home page online and identifying a picture or gendered pronoun pointing to a gender assignment. Author first names were not used to assign them a gender, even when apparently obvious. This produced a list of apparently correct genders for the researchers, which was used to compare with the results of the automatic method.

Compared to the human-classified genders, the automatic method had precision of $97.5 \%$ and recall of $66.4 \%$ for men with a gender that could be identified online. The gender assignment program was therefore rarely incorrect when deciding that a UK researcher was male (only $2.5 \%$ errors for this) but could only find about two thirds (66.4\%) of the male researchers in the set (the rest were classified as female or unknown). The method had a corresponding precision of $99.5 \%$ and recall of $70.8 \%$ for women with a gender that could be detected online. The gender assignment program was therefore almost never incorrect when deciding that a UK researcher was female (only $0.5 \%$ errors for this) and could find well over two thirds (70.8\%) of the female researchers in the set (the rest were classified as male or unknown).

\section{RQ1: Proportion of articles in each broad and narrow field, by first author gender}

For each broad and narrow field, the proportion of articles with a male or female first author was calculated. Because the gender detection algorithm is more accurate for women than for men, a direct comparison of the numbers of male 
and female first-authored articles in each field for RQ1, as detected by the algorithm, would be misleading. A correction factor was therefore calculated to give a corrected estimate of the number of male and female first authored articles in each field. Multiplying by precision/recall gives a correction factor to estimate the number of UK first authors of each gender, 1.470 for men and 1.406 for women. This compensates both for occasional gender classification errors and for more female UK scientist first names being detectable. The same procedure has been applied to the US data used for comparisons (with a set of US author name data) so that the results should not be influenced by international differences in the rate of detecting male or female genders from names.

The results were analysed with the people/things theoretical dimensions discussed above because these are relatively straightforward to apply to fields (i.e., the extent to which the fields involve people or things) in comparison to the communal/agentic goals theory (i.e., the extent to which the fields satisfy personal communal or agentic goals). To aid a discussion of the people/things dimensions, classifications of the broad and narrow fields singled out for discussion were taken from a prior paper (Table A1 of: Thelwall; Bailey; Makita; Sud; Madalli, 2019). These had been made by three people with a library science degree or PhD on the scale of 1 (very people-oriented subject) to 5 (very thing-oriented subject). The score for each field was the score chosen by at least two, otherwise the average of the three.

\section{RQ2a: Words used more often by one gender in article titles, abstracts and keywords overall}

All words were extracted from the titles, abstract and keywords of all gendered articles in the dataset. The number of articles containing each word was calculated separately for men and women to give an overall gendered word frequency table. The number of articles in each of the 308 narrow fields containing each word was also calculated separately for men and women, giving an additional 308 field specific gendered word frequency tables.

For each word in the overall gendered word frequency table, a $2 \times 2$ chi-squared test was employed to detect whether there was statistical evidence that it was used disproportionately often by UK male or female first authors. To give a simple example with artificially low numbers, if the term family was used in 20 out of 1000 female first-authored articles $(2 \%)$ and 5 out of 500 male first-authored articles (1\%) then the chi-squared value of 2.03 for the resulting $2 \times 2$ table is insufficiently large to reject the null hypothesis that the two genders have the same underlying tendency to use the term family in their research. Thus, whilst there could be a gender difference in the use of this term, the gender disparity is not large enough to support this conclusion. The first name gender detection precisions are high enough for these tests to be accurate. All gender assignment errors would weaken the power of a test but would not generate spurious results because they would only add noise to the data.

Since this chi-squared test was repeated for each term, there is a high chance of spurious positives (i.e., evidence of a gender difference when the difference in the data is due to chance factors rather than an underlying gender difference in tendency to use the term). This was guarded against with the Benjamini-Hochberg (1995) procedure, which increases the chi-squared threshold in a systematic way that keeps the chance of making at least one false positive conclusion below $5 \%$. Terms that occurred too infrequently to give a positive chi-squared test were first discarded to increase the power of the Benjamini-Hochberg procedure.

The result of this procedure is a list of terms for which there is statistical evidence of gender differences in their use by researchers to use in journal article titles, abstracts or keywords.

\section{RQ2b: Words used more often by one gender in article titles, abstracts and keywords within narrow fields}

The above science-wide list is likely to generate terms that are closely associated with research topics but may not identify gender differences that occur between authors researching the same topic (e.g., recurring methods choices). To search for these, for each narrow field having at least 50 articles with gendered authors, a list of the 20 most gendered terms was generated from the field specific gendered word frequency tables mentioned above using the chi-squared test described above, but without the Benjamini-Hochberg correction. This produced a set of lists of gendered terms, one for each narrow field.

The narrow field gendered term lists were then merged and terms that occurred in at least 12 were reported. These are terms that have gender differences in use in at least 12 fields. Terms with less than $70 \%$ of the differences being in the same gender direction were excluded. Whilst this is not a rigorous statistical procedure and the numbers 20 and 12 above were arbitrarily chosen, it produces terms that are likely to have gendered associations across multiple narrow fields. The threshold of 50 above was chosen heuristically as large enough to remove small fields for which gender differences could be due to a small number of authors.

The result of this procedure is a list of terms that are frequently most used by the same gender in multiple narrow fields.

\section{RQ2ab: Reasons for gender differences in term use}

The above two procedures (sections RQ2a and RQ2b) produced lists of words used disproportionately often by one gender overall or within multiple narrow fields but did not give insights into why these differences occurred. For some words, the reasons might be guessed but for others there was not a clear reason and so all gendered words detected were systematically investigated to find out why there was a gender disparity. Reading a sample of articles containing a term is insufficient because this can reveal why a term is used by not why it is used more by one gender. Follow-up word 
association analyses were used instead because these can take into account differences between genders and fields.

For each gendered word, three word association analyses (as described below) were conducted and triangulated to detect the core issue causing the gender imbalance in its use (see Table 3 for an explanation of the codes).
Table 3. Four categories of paper based on the first author gender and whether the paper title, abstract or keywords contained a given term.

\begin{tabular}{|l|c|c|}
\hline \multicolumn{1}{|c|}{ Paper content $\backslash$ First author gender } & Male & Female \\
\hline With term & MW & FW \\
\hline Without term & MO & FO \\
\hline
\end{tabular}

- Overall gendered term use: A word association analysis examined terms that occurred more often in articles written by the selected gender authors and containing the term compared to the remaining articles (men: $\mathrm{MW} v$ s. $\mathrm{FW}+\mathrm{MO}+\mathrm{FO}$; women: $\mathrm{FW}$ vs. MW+MO+FO).

- Term use by each gender separately: A word association analysis examined terms that occurred more often in articles written by the selected gender authors and containing the term, compared to articles written by the same gender authors and not containing the term (men: MW vs. MO; women: FW vs. FO).

- Gender differences in use of the term: A word association analysis examined words that were more frequent for the selected gender than the other gender for documents containing the term (men: MW vs. FW; women: FW vs. MW).

A word association analysis involves examining words that frequently occur in the same document as the target word. Each word association analysis here consisted of the first author:

- Visually inspecting the list of terms that associate with the selected word.

- Reading 40 matching article titles/descriptions/keywords using the Key Word in Context (KWIC) approach, selected using a random number generator (for the first one of the three word association analyses only since the results are the same).

- Combining the first two steps to identify the underlying cause(s) or semantic/contextual patterns.

For example, the FW vs. MW+MO+FO word association analysis for the female term coded found 89 associating terms (i.e., terms often found in female documents containing coded), including: thematically, filmed, transcribed, verbatim, mealtime, interview, thirty-five, cluster-randomised, theme, alcohol-related, staff, coding, qualitative, checked. The first random KWIC selection was the sentence, "Interviews were transcribed, coded and analyzed using framework" from the abstract of the article, "Qualitative study of welcome houses: a recent initiative designed to improve retention in therapeutic communities". After scanning the complete list of 89 terms and $40 \mathrm{KWIC}$ results and repeating this for the other two word association analyses (FW vs. FO and FW vs. MW), the female-associated term coded was classed as having a female association due to its use in describing research interviews.

The time-consuming nature of this categorisation process (typical for qualitative methods) is necessary because of term ambiguity. For example, the term coded was frequently used in the dataset in the context of signal processing and programming, but these uses did not cause the gender bias in favour of women.

\section{RQ2ab: Categories of reasons for gender differences in term use}

The word association analysis results were used by the first author to categorise each term found by either word frequency analysis (overall and within subject) into broad and narrow themes, as reported in the last two tables in this paper. For example, the term coded was eventually grouped within the theme Interview inside the larger category Qualitative Methods.

The broad and narrow themes were chosen to align with the similar themes reported for the prior USA paper as far as possible to so that any international differences found could not be due to differences in the classification process. With this approach, UK-USA differences should only occur when the UK data cannot fit the USA situation rather than when a different UK explanation is selected from a range of plausible explanations that might include that chosen for the USA.

\section{Results}

The results are briefly analysed in terms of the people/things dichotomy and prior USA findings.

\section{RQ1: Research fields}

There are substantial variations in gender disparities for broad fields, with over twice as many female first-authored papers in Veterinary Science and Nursing, and over three times as many male first-authored papers in Mathematics and Physics (Table 4).

The rank order of the broad fields reflects the people/things dimensions to some extent, but not closely. Ignoring the small Veterinary Science broad field, people-oriented Nursing and Psychology are at the top and thing-oriented Physics and Astronomy, Computer Science, Engineering, and Mathematics are at the bottom. Both Veterinary Science and Immunology and Microbiology have a high proportion of female first authors, despite not focusing on people. Similarly, Economics, Econometrics \& Finance is near the bottom, despite an apparent absence of things. 
Table 4. First author gender ratios for all 26 Scopus broad fields together the subfields with the highest and lowest ratios of female-authored papers to male-authored papers (qualification for the 237 narrow subfields: at least 50 gendered UK first authored Scopus journal articles in 2017; $\mathrm{n}=92,058$ articles overall). F/M odds ratios were multiplied by $1.406 / 1.470$ to correct first name gender identification biases. Values from the USA are included for comparison (Thelwall; Bailey, Tobin; Bradshaw, 2019).

\begin{tabular}{|c|c|c|c|c|c|c|}
\hline Broad field & $\begin{array}{l}\text { Fields/ } \\
\text { Used }\end{array}$ & $\begin{array}{l}\text { F/M } \\
\text { UK }\end{array}$ & $\begin{array}{l}\text { F/M } \\
\text { USA* }\end{array}$ & $\begin{array}{l}\mathbf{P} / \mathbf{T} \\
* *\end{array}$ & $\begin{array}{l}\text { Most female narrow subfield }{ }^{* * *} \\
\text { Most male narrow subfield }\end{array}$ & $\begin{array}{l}\text { F/M } \\
\text { UK }\end{array}$ \\
\hline \multirow{2}{*}{$\begin{array}{l}\text { Veterinary } \\
(\mathrm{n}=67)\end{array}$} & 4 & \multirow{2}{*}{2.25} & \multirow{2}{*}{1.49} & \multirow{2}{*}{2.7} & - & \\
\hline & 0 & & & & - & \\
\hline \multirow{2}{*}{ Nursing } & 21 & \multirow{2}{*}{2.11} & \multirow{2}{*}{1.93} & \multirow{2}{*}{1} & Maternity and Midwifery & 19.13 \\
\hline & 8 & & & & Issues, Ethics and Legal Aspects & 0.98 \\
\hline \multirow{2}{*}{ Psychology } & 7 & \multirow{2}{*}{1.51} & \multirow{2}{*}{0.93} & \multirow{2}{*}{2} & Developmental and Educational Psychology & 2.13 \\
\hline & 7 & & & & Experimental and Cognitive Psychology & 1.13 \\
\hline \multirow{2}{*}{ Immunology \& Microbiology } & 6 & \multirow{2}{*}{1.32} & \multirow{2}{*}{$0.75^{*}$} & \multirow{2}{*}{3} & Parasitology & 1.62 \\
\hline & 5 & & & & Applied Microbiology and Biotechnology & 0.82 \\
\hline \multirow{2}{*}{ Neuroscience } & 9 & \multirow{2}{*}{1.08} & \multirow{2}{*}{0.82} & 3 & Cognitive Neuroscience & 1.43 \\
\hline & 7 & & & 3 & Sensory Systems & 0.74 \\
\hline Medirine & 47 & 105 & 074 & 2 & Obstetrics and Gynecology & 2.48 \\
\hline Ivedicinte & 42 & 1.05 & 0.14 & 2 & Orthopedics and Sports Medicine & 0.41 \\
\hline Dentictry & 4 & 096 & $033 *$ & 1 & - & \\
\hline Dentistry & 0 & 0.90 & 0.35 & 1 & - & \\
\hline Serial Sriencec & 22 & 093 & 076 & 2 & Gender Studies & 4.75 \\
\hline soclal sciences & 22 & 0.93 & 0.16 & 2 & Human Factors and Ergonomics & 0.55 \\
\hline Biochemistry, Genetics \& Molecular & 15 & 097 & $067 *$ & 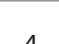 & Aging & 1.64 \\
\hline Biology & 14 & 0.81 & $0.0 /$ & 4 & Structural Biology & 0.51 \\
\hline Health Profecsionc & 13 & 085 & $099 *$ & 1 & Speech and Hearing & 2.62 \\
\hline Healtn protessions & 3 & 0.85 & $0.99^{n}$ & 1 & Physical Therapy, Sports Therapy \& Rehab. & 0.57 \\
\hline & 5 & 083 & & 27 & Toxicology & 1.24 \\
\hline Pharma, Ioxıcology \& Pharmaceutics & 4 & 0.83 & 0.69 & 2.1 & Drug Discovery & 0.52 \\
\hline Arts \& Humanities & 13 & 074 & 064 & 2 & Language and Linguistics & 1.31 \\
\hline & 11 & 0.14 & 0.64 & 2 & Philosophy & 0.38 \\
\hline Aaricultural \& Biological Sciences & 11 & 072 & 049 & 4 & Animal Science and Zoology & 1.05 \\
\hline Agricuitural \& Blological sclences & 10 & 0.12 & 0.49 & 4 & Soil Sciences & 0.44 \\
\hline Envirenmental Scionce & 12 & 070 & 052 & 3 & Health, Toxicology and Mutagenesis & 1.05 \\
\hline Emvironmentar science & 12 & 0.10 & 0.52 & 3 & Ecological Modeling & 0.40 \\
\hline Businecs Management \& Accounting & 10 & 062 & 047 & 2 & Marketing & 1.01 \\
\hline Bustness, IVIanagement \& Accounting & 8 & 0.02 & $0.4 /$ & 2 & Organizational Behavior \& Hum. Res. Man. & 0.60 \\
\hline Chemictry & 7 & 048 & 030 & 5 & Inorganic Chemistry & 0.64 \\
\hline cremistry & 6 & 0.40 & 0.39 & 3 & Physical and Theoretical Chemistry & 0.38 \\
\hline Matoriale Crionse & 8 & 010 & 30 & 5 & Polymers and Plastics & 0.65 \\
\hline IVlaterlais science & 7 & 0.48 & 0.39 & 5 & Electronic, Optical \& Magnetic Materials & 0.35 \\
\hline & 3 & 0.48 & $032 *$ & 4 & Information Systems and Management & 0.54 \\
\hline Decision Sciences & 3 & 0.48 & $0.32^{*}$ & 4 & Statistics, Probability and Uncertainty & 0.41 \\
\hline & 5 & 047 & $026 *$ & 5 & Renew. Energy, Sustainability \& Environment & 0.57 \\
\hline Energy & 4 & $0.4 /$ & $0.26^{*}$ & 5 & Energy Engineering and Power Technology & 0.39 \\
\hline Chemical Engineoring & 8 & 0.47 & $047 *$ & 5 & Catalysis & 0.50 \\
\hline Chemıcal Engıneerıng & 5 & $0.4 /$ & $0.4 /^{\pi}$ & 5 & Fluid Flow and Transfer Processes & 0.12 \\
\hline & 13 & 012 & 035 & 27 & Stratigraphy & 0.63 \\
\hline Earth \& Planetary Sciences & 11 & 0.43 & 0.35 & 3.1 & Geotechnical Eng. \& Engineering Geology & 0.30 \\
\hline Economics Econometrics \& Finance & 3 & 041 & 028 & 3 & Economics and Econometrics & 0.40 \\
\hline Economics, Econometrics \& finance & 3 & 0.41 & 0.28 & 3 & Finance & 0.37 \\
\hline Enginonring & 16 & 0,0 & 032 & 5 & Media Technology & 0.67 \\
\hline Engineering & 14 & 0.40 & 0.32 & 3 & Engineering (misc) & 0.22 \\
\hline Semputer Scienco & 12 & $0 \Delta 0$ & 030 & 5 & Human-Computer Interaction & 0.82 \\
\hline computer science & 11 & 0.40 & 0.30 & 5 & Hardware and Architecture & 0.23 \\
\hline Phycirs \& Actronomy & 10 & 030 & $0 ? 4$ & 5 & Acoustics and Ultrasonics & 0.41 \\
\hline Pnysics \& Astronomy & 10 & 0.30 & 0.24 & 3 & Statistical and Nonlinear Physics & 0.20 \\
\hline & 14 & 027 & 027 & 5 & Modeling and Simulation & 0.38 \\
\hline Mathematıcs & 10 & 0.21 & 0.22 & 5 & Geometry and Topology & 0.08 \\
\hline
\end{tabular}

*large UK/US rank differences;

**P/T: People-thing orientation estimated by three librarians independent of this project (1=very people-oriented subject $-5=$ very thing-oriented subject).

$* * *$ hyphens indicate no qualifying ( $>50$ articles) fields 
Individual narrow fields with over 50 gendered articles reveal more extreme gender imbalances, from Maternity and Midwifery (19 female first-authored articles for every male first-authored article) to Geometry and Topology (12.5 male first-authored articles for every female first-authored article). For gendered UK first authored articles, a female first author in Maternity and Midwifery is therefore 240 times more likely than in Geometry and Topology.

The results reflect the same broad people/thing pattern as the USA and some of the exceptions. Compared to the USA, there are more UK female first authors overall (UK: 43\%; USA: 37\%, after applying correction factors to both). This may be related to the slightly lower gender disparities in general employment in the UK (UNDP, 2016 as mentioned above). There may also be other systemic causes of the overall UK-US differences related to tenure and academic employment differences, such as more women in teaching-focused institutions or jobs. There are more female first authors than in the USA in all broad fields except one (Health Professions) and one tie (Chemical Engineering). Taking this into account, the small Veterinary Science and Dentistry areas are much more female in the UK, as are: Biochemistry, Genetics and Molecular Biology; Decision Sciences; and Energy. Psychology is ranked third in both countries but is male in the USA and substantially female in the UK. Conversely, two areas are more male in the UK: Health Professions; Chemical Engineering (the same UK-USA F/M ratios, but lower ranked in the UK than the USA).

The Arts and Humanities broad area is analysed in detail here because it includes contrasting fields with subjects that non-experts can recognise (Table 5). There are moderately varying gender disparities. The people/thing dimensions provide little explanation for these results because performing arts is the only component with an explicit focus on people, whilst Conservation has a focus on things and both Archeology (arts and humanities) and Music have elements of things (artefacts, instruments respectively). The most male field, Philosophy, is also the only abstract field. As for the USA, this field is an exception to the people/things hypothesis. The position of Music is influenced by the inclusion of technical articles about music in some journals in this category.

Compared to the USA, the Arts and Humanities are more female overall in the UK. The rank orders of the Arts and Humanities subfields are broadly similar, except that Music is much more male in the UK. In the case of Music, its male skewing in the UK compared to the USA reflects extra computer science research into music technology in the UK rather than a difference in core arts and humanities music research. For example, $14 \%$ of UK Music
Table 5. First author gender ratios for Arts and Humanities subfields with at least 50 gendered UK first authored Scopus journal articles in 2017). Values from the USA are included for comparison (Thelwall; Bailey; Tobin; Bradshaw, 2019).

\begin{tabular}{|l|c|c|c|}
\hline \multirow{2}{*}{ Narrow field } & \multirow{2}{*}{ P/T* } & \multicolumn{2}{c|}{ F/M** } \\
\cline { 3 - 5 } & & UK & USA \\
\hline Language and Linguistics & 2 & 1.31 & 0.97 \\
\hline Visual Arts and Performing Arts & 1 & 1.10 & 1.00 \\
\hline Arts and Humanities (misc) & 2 & 0.99 & 0.75 \\
\hline Conservation & 4 & 0.99 & 0.91 \\
\hline Literature and Literary Theory & 3 & 0.87 & 0.72 \\
\hline History & 2 & 0.67 & 0.44 \\
\hline Archeology (arts and humanities) & 2.7 & 0.63 & 0.46 \\
\hline History and Philosophy of Science & 2 & 0.51 & 0.58 \\
\hline Religious Studies & 1 & 0.51 & 0.34 \\
\hline Music & 1 & 0.46 & 0.70 \\
\hline Philosophy & 2 & 0.38 & 0.28 \\
\hline
\end{tabular}

*P/T: People-thing orientation estimated by three librarians independent of this project ( 1 =very people-oriented subject $-5=$ very thing-oriented subject). ** F/M odds ratios were multiplied by $1.406 / 1.470$ to correct first name gender identification biases.

Table 6. First author gender ratios for Social Sciences subfields with at least 50 gendered UK first authored Scopus journal articles in 2017). Values from the USA are included for comparison (Thelwall; Bailey; Tobin; Bradshaw, 2019).

\begin{tabular}{|c|c|c|c|}
\hline \multirow{2}{*}{ Narrow field } & \multirow{2}{*}{$\mathbf{P} / \mathbf{T}^{*}$} & \multicolumn{2}{|c|}{$\mathbf{F} / \mathbf{M}^{* *}$} \\
\hline & & UK & USA \\
\hline Gender Studies & 1 & 4.75 & 1.86 \\
\hline Demography & 1 & 1.59 & 1.15 \\
\hline Life-span and Life-course Studies & 1 & 1.50 & 1.33 \\
\hline Health (social science) & 1 & 1.40 & 1.45 \\
\hline Linguistics and Language & 2 & 1.32 & 1.07 \\
\hline Education & 1 & 1.28 & 1.17 \\
\hline Social Sciences (misc) & 2 & 1.25 & 1.04 \\
\hline Anthropology & 1 & 1.19 & 0.93 \\
\hline Communication & 1 & 0.90 & 0.98 \\
\hline Library and Information Sciences & 3 & 0.88 & 1.14 \\
\hline Cultural Studies & 2 & 0.87 & 0.83 \\
\hline Sociology and Political Science & 2 & 0.85 & 0.65 \\
\hline Public Administration & 1 & 0.83 & 0.58 \\
\hline Law & 2 & 0.77 & 0.53 \\
\hline Development & 3 & 0.76 & 0.59 \\
\hline Transportation & 3 & 0.71 & 0.54 \\
\hline Geography, Planning and Development & 3 & 0.66 & 0.56 \\
\hline Urban Studies & 2 & 0.63 & 0.52 \\
\hline Safety Research & 2 & 0.60 & 0.48 \\
\hline Archeology & 3 & 0.60 & 0.42 \\
\hline Political Science and International Relations & 2 & 0.57 & 0.31 \\
\hline Human Factors and Ergonomics & 1 & 0.55 & 0.41 \\
\hline
\end{tabular}

*P/T: People-thing orientation estimated by three librarians independent of this project (1=very people-oriented subject - 5=very thing-oriented subject).

$* * \mathrm{~F} / \mathrm{M}$ odds ratios were multiplied by $1.406 / 1.470$ to correct first name gender identification biases. 
research is also classified as Computer Science in comparison to $8 \%$ for the USA and $6 \%$ is dual classified as Physics compared to $1 \%$ for the USA. More UK research ( $6 \%$ vs. $1 \%$ ) is published in Journal of The Audio Engineering Society. This difference is therefore not illuminating about people/things exceptions but is more about Scopus journal categorisation choices impacting the UK and USA differently.

Social Sciences subfields are also varied in topic and are mostly related to people collectively, some indirectly (e.g., Archeology) and others directly (e.g., Gender Studies, Education). There are few thing dimensions, with the main exceptions being aspects of Transportation, Safety Research, Archeology, and Human Factors and Ergonomics (the librarian classification of this field as very people-oriented does not seem correct: Table A1 in: Thelwall; Bailey; Makita; Sud; Madalli, 2019), all of which are in the lower half of Table 6. There are moderate gender disparity differences between narrow subfields, except for Gender Studies, which has almost five female first-authored articles for every male first-authored article. The results therefore broadly align with the people/things hypothesis without serious exceptions. There is also a tendency for power/control fields (Law, Safety Research, Political Science and International Relations; also Economics in Table 2) to have a greater share of male first-authored articles, as in the USA.

The rank order of the Social Sciences subfields is very similar to that of the USA. The biggest rank anomaly is Library and Information Sciences. This is a relatively minor change, despite being female in the USA and male in the UK. The biggest numerical contrast between the two countries is that Gender Studies is over twice as female in the UK compared to the USA. This may be due to a greater focus on LGBTQ issues in the USA. USA articles are more likely to contain the terms gay (14\% against $8 \%$ for the UK), lesbian ( $13 \%$ vs. $3 \%$ ), bisexual ( $10 \%$ vs. $2 \%$ ), transgender ( $9 \%$ vs. $4 \%$ ), and queer ( $8 \%$ vs. $6 \%$ ). In contrast, UK articles are more likely to mention women (49\% against $38 \%$ for the USA) and feminist (19\% vs. $14 \%$ ). Thus, there is an international difference in gender specialisms. This may be a cause or effect of the gender disparities in publishing between them.

\section{RQ2: Research topics, methods and styles}

Many of the terms that were statistically significantly used more by women were apparently gender neutral, such as functioning (Table 7), which needs explaining. After reading titles and abstracts of articles containing functioning and running co-word analyses of functioning (as for all words; see methods) it was detected to be typically used within psychology. Its statistically greater use by women is therefore a second order effect of the higher share of female first authors in some psychology narrow fields.

Most of the female-associated topics found by the word association analyses of terms that are gendered in the overall dataset and/or within at least 12 narrow fields are about people or have a direct connection to people (Table 7). Some, but not all, of these have a caring (Health \& wellbeing) or nurturing (Education) dimension.

Two of the other broad themes are connected to people. Qualitative methods are also female-associated. They are presumably employed primarily to investigate data from interviews or questionnaires, and so are likely to be part of people-focused research projects. The same is true for the (predominantly) quantitative method, surveys.

The fourth broad theme, Life sciences, is not directly about people or part of projects necessarily involving people. This is the clearest example of an exception to the people dimension for female research.

In comparison to the USA (for tables, see: Thelwall; Bailey; Tobin; Bradshaw, 2019), the UK has a stronger life sciences trend for women. Only cell biology within the life sciences was significantly female-associated in the USA. In the USA, there was a gender inequality theme (terms: sexism, gendered) that was not found for the UK. Perhaps most significantly, the cell biology exception to the people/things theory previously found for the USA could be extended based on these results to encompass genetics and life sciences experiments. Interviews, surveys and qualitative methods were also found for the USA. things theory previously found for the USA could be extended based on these results to encompass genetics and life sciences experiments
The cell biology exception to the people/ 
Table 7. Broad themes for terms occurring in a statistically significantly higher proportion of female first-authored articles than male first-authored articles (standard font).

\begin{tabular}{|c|c|c|}
\hline Broad theme & Narrow theme & Terms used more by female first authors* \\
\hline \multirow{3}{*}{ Life sciences } & Cell/molecular biology & cell, pathway, promote, culture, protein \\
\hline & Genetics & gene, phenotype, mice \\
\hline & Life sciences experiments & vitro, vivo \\
\hline \multirow{9}{*}{ People } & Communication & partnership, discourse, communication, engagement, language \\
\hline & Education & $\begin{array}{l}\text { development, education, higher, learning, literacy, school, skill, student, teacher, } \\
\text { training }\end{array}$ \\
\hline & General & individual, people, person, population, their, who, they \\
\hline & Health \& wellbeing & $\begin{array}{l}\text { dietary, clinical, hospital, pregnancies, disability, cancer, illness, impact, nursing, dis- } \\
\text { tress, health, care [111 terms] }\end{array}$ \\
\hline & Psychology & developing, behavioural, functioning, emotion, feeling, cognitive \\
\hline & Role & $\begin{array}{l}\text { family, families, father, worker, recruited, mother, motherhood, parent, parenting, prac- } \\
\text { titioner, professional, staff, partner }\end{array}$ \\
\hline & Services & experiencing, provider, provision, practice \\
\hline & Social context & community, social \\
\hline & Type & $\begin{array}{l}\text { female, her, women, feminist, gender, men, adult, age, older, children, girl, young, } \\
\text { [21 terms] }\end{array}$ \\
\hline \multirow[b]{2}{*}{ Qualitative methods } & Interview & $\begin{array}{l}\text { coded, completed, engage, facilitator, felt, in-depth, interview, interviewed, living, } \\
\text { need, perceived, semi-structured, support, transcribed, verbatim, working }\end{array}$ \\
\hline & General & $\begin{array}{l}\text { experience, association, cross-sectional, ethnographic, explore, study, experience, } \\
\text { focus, inductive, inform, narrative, negotiating, participant, perspective, qualitative, } \\
\text { thematic, understanding, phenomenological, stories [ } 27 \text { terms] }\end{array}$ \\
\hline Quantitative methods & Survey & online, questionnaire, self-report, telephone \\
\hline
\end{tabular}

* The top 20 gendered terms for at least 12 narrow fields were all also gendered overall and are bold. The themes reported were identified by word association analyses, as described in the methods.

Things and their properties are male-associated broad themes, including abstract things, such as systems, and abstract properties, such as two-dimensional (Table 8). Many quantitative methods terms are male-associated, including several for computing and modelling. These quantitative methods may be part of investigations of things (e.g., engines) or abstractions (e.g., models). Abstractions are a male-associated broad theme, including both theory and pure mathematics. Male first authors are also more likely to use terms signifying an argument style of writing, as in the corresponding analysis of the US (where reply, erroneous were male associated for the USA). The people term his is male associated but this is typically used by men when referring to prominent historical or political figures. These are presumably analysed indirectly thorough their writings or activities.

The UK male themes were found in the corresponding USA data, except for individual prominent men, which is a people-related theme. It may be an abstraction of people because it about their actions or writings rather than involving

Table 8. Broad themes for terms occurring in a statistically significantly higher proportion of male first-authored articles than male first-authored articles (standard font).

\begin{tabular}{|c|c|c|}
\hline Broad theme & Narrow theme & Terms used more by male first authors* \\
\hline \multirow{2}{*}{ Abstract } & Abstract & theory \\
\hline & Pure maths & infinite, symmetry, arbitrary, conjecture, finite, prove, theorem \\
\hline Argument & General & recent, argument, paper, state \\
\hline People & Individual prominent men & his \\
\hline \multirow{4}{*}{ Quantitative methods } & General & 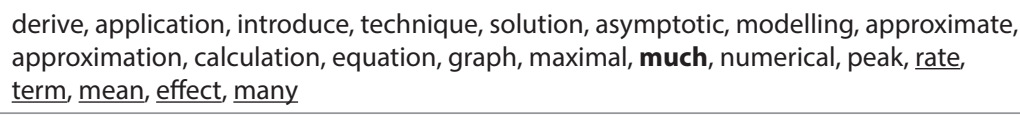 \\
\hline & Computing & algorithm, computation, computing, machine, computer, computational \\
\hline & Model & extension, gaussian, distribution, model, parameter, stochastic, classical, lead \\
\hline & Simulation & dynamic, simulation, configuration \\
\hline \multirow[b]{2}{*}{ Things } & Objects & sensor, system, these, an, it \\
\hline & Properties & $\begin{array}{l}\text { boundary, regime, energy, evolution, flow, hydrodynamic, metal, simple, phenomena, } \\
\text { motion, coupling, field, gravity, physics, operation, yield, properties, quantum, spectra, } \\
\text { planar, plane, topology, two-dimensional, structure, surface, output }\end{array}$ \\
\hline
\end{tabular}

* Terms that occur in the top 20 gendered terms for at least 12 narrow fields are underlined (there were no terms in this category for the female set, Table 7). Terms that are both (gendered overall and within at least 12 narrow fields) are bold. The themes reported were identified by word association analyses, as described in the methods. 
personal interactions with them or helping them. Themes found for the USA but not the UK include surgery, medical imaging, religion and patients. Because of the relatively arbitrary statistical and other thresholds used to generate these lists, it is not possible to draw strong conclusions from these differences. In confirmation of this, the narrow fields Surgery (F/M: 0.50) and Religious Studies (F/M: 0.51) are male in the UK. The term patients is a more complex case. It is slightly female gendered overall in the USA (19.2\% of male and $19.8 \%$ of female first-authored USA Scopus articles contain this term) and strongly female in the UK (12.2\% of male and $16.3 \%$ of female). It was cast as a male-associated term in the USA because it was male-associated in many narrow fields. Nevertheless, comparing the UK and USA percentages above, UK men are relatively less likely to write about patients. Medical imaging is male in the UK but too small a specialism to create a statistically significant result (16 gendered author articles contain angiographic, 13 of which are male first-authored). Overall, then, the UK results suggest that the male orientation of patient-related research within some narrow fields may be specific to the USA but the other differences may not be significant.

\section{Discussion}

This paper analyses UK academia from the perspective of published journal articles, which largely hides the arts, humanities and some social sciences because of their differing research outputs. Non-academics may also publish research (e.g., medical doctors) and women may publish fewer articles due to their research styles (qualitative research may be slower and health research may involve more extensive ethics checks), practice requirements (e.g., nurse lecturers may need to undertake periodic nursing practice), greater (average) teaching load (at least two decades ago: Xie; Shauman, 1998) or extra service work (e.g., Guarino; Borden, 2017). Another limitation is that there can be differences in the interpretation or performance of gender between regions of the same country (e.g., for the USA: Chang, 1999) and this is probably true in the UK. A high proportion (32\%) of UK academics had non-UK nationality in 2017/8 (HESA, 2019) and may bring differing international gendered expectations about research and research publishing with them. This varies from 13\% in Education to 45\% in Engineering (HESA, 2019). Thus, the gender disparity differences between fields in the UK (and USA) are partly due to international gender disparities and differing field abilities to recruit researchers of other nationalities. The Scopus classification scheme is a limitation, especially for its occasional use of inappropriate categories for journals. The use of statistical results for terms is also a restriction due to their use of null hypothesis significance testing or cut-off thresholds (Tables 5,6 ) and so an absence of a term does not imply that it is not gendered. The term comparison differences may be partly due to gender differences in writing styles rather than substantive differences in research methods or topics.

An important theoretical issue that the methods here do not address is the nature of the causes of the gender differences found. Whilst it seems likely that field specialisms primarily reflect the personal preferences of the researchers involved, these will be influenced by social constraints about what is expected or desirable for men and women. They are also likely to be affected by early family and social expectations influencing education, such as the likelihood of signing up for extra computing classes or clubs, or engaging in leisure time co-curricular activities related to art, animals or sport. Thus, the adults making career decisions will have skills and desires shaped by gender-influenced choices and constraints throughout their lives.

The comparisons between the UK and USA also do not reflect the causes of the differences found. These are likely to include national differences in higher education structures and specialisms and, particularly in the humanities and social sciences, the social and political histories of the two countries. For example, the greater academic interest in LGBTQ issues in the USA within Gender Studies may reflect a more urgent need to address prejudices in this country or greater experience of intolerance by LGBTQ community members.

\section{Publication frequency and academic community demographics}

It is possible to assess whether publication frequency reflects the composition of the UK academic community to some extent. Since men may tend to write more journal articles than women, as mentioned above, there may be a systematic male bias in the publication analysis here.

The 2016/7 UK postgraduate cohort (Table 1) was more female than the UK publications (Table 4,5,6), but this may be due to the legacy of fewer women in the education system in previous years. Large anomalies include Education (F/M: 2.12 for postgraduates; F/M: 1.28 for publications), which may be due more women choosing to teach, and Biological Sciences (F/M: 1.59 for postgraduates; F/M: 0.87 for publications in Biochemistry, Genetics and Molecular Biology), presumably due to the inclusion of biochemistry in the latter category. Comparing publications to full-time or part time academic staff (Table 2), there is a higher proportion of women working (46\%) than female first-authored publications $(43 \%)$ but this could be due to women being more likely to work in specialisms with lower publishing frequency. The F/M ratios are broadly similar between staff (Table 2 ) and publications (Table 4,5,6) except that there is a substantially higher proportion of women working in Nursing (F/M: 2.99 for staff; 2.11 for publications), Education (F/M: 2.02 for staff; 1.28 for publications), and Law (F/M: 1.07 for staff; 0.77 for publications). Since these are professional areas, it is 
possible that women may practice part time rather than research, or that male non-academic practitioners are more likely to publish. Conversely, there is a substantially lower proportion of women working than publishing in Veterinary Science (F/M: 1.16 for staff; 2.25 for publications) and various types of engineering (F/M: 0.17-0.35 for staff; 0.40-0.47 for publications). Perhaps male veterinarians and engineers are more interested in practical work and less interested in, or capable of, academic writing.

All the explanations suggested in this section are tentative, both because of the differing classification schemes compared and the lack of evidence for the causes suggested.

\section{UK vs. USA and people/things interests vs. communal/agentic goals}

The UK results broadly conform to the people/things hypothesis with many of the same exceptions as the USA, such as power/control fields having many male first authors. This strengthens the US evidence for the people/things hypothesis being insufficient to explain all gender disparities, and for power/control being a male-associated people aspect. The male association with power/control aligns better with the communal/agentic goals theory since power/control would be an agentic career goal. The power/control dimension may also relate to the status of a subject, which would be an agentic goal. Thus, an important determinant of gender disparities within academic subjects may be the extent to which they are perceived as fulfilling communal or agentic goals.

There are differences between the UK and USA in the degree of gendering in many broad fields, including Veterinary Science, Psychology and Health Professions. The results also suggest that the cell biology exception found for the USA extend to genetics and life sciences experiments in the UK, reflecting a stronger female life sciences axis than previously found. It does not extend to all the life/biological sciences, at least as expressed in the combined broad field Biochemistry, Genetics and Molecular Biology, partly due to the latter's inclusion of chemistry-related research and relatively abstract fields, such as structural biology. This confirms cell biology (and perhaps related specialisms) as a female-associated non-people area. From the communal/agentic goals theory perspective, if cell biology is perceived to be important for communal goals, such as by helping to fight cancer and other diseases, then this would explain the gender disparity.

Mentioning patients was clearly female gendered in the UK whereas it was male gendered within many USA narrow fields, but not overall. Together with patients being people-oriented, this suggests that the previously hypothesised patients topic exception to the people/things hypothesis may be an anomaly for the USA rather than a more general trend. This might be due to greater pay and status for medical-related academics in the USA, in the absence of nationally agreed pay scales. Since patient-based research might be primarily conducted by medical doctors, which is a high-status profession, it could satisfy both agentic and communal goals.

It is difficult to draw strong conclusions from the differences between the UK and USA because the two countries have different research specialisms, which can affect the comparisons between them. These differences (e.g., women vs LGBTQ in Gender Studies) may be for historical or political reasons rather than differing gender roles or expectations. Thus, the strongest findings from this paper are the confirmation of the people/things hypothesis as a loose framework and several robust exceptions, that are better explained by the communal/agentic goals theory.

Since the UK and USA have many similarities in terms of culture, the explanatory power of the people/things and communal/agentic goals theory results should not be generalised to countries in which genders have different meanings and expectations, and in which the economic constraints on gender roles are stronger. Nevertheless, it would be reasonable to expect the results to be broadly applicable to richer English-speaking countries that would have a similar culture and economic context for career decision making and it would be useful to test the extent to which they apply elsewhere. It would be interesting to apply a similar analysis to countries with other languages and cultures, although the word-based results would not be directly comparable.

The communal/agentic goals theory seems to be a better fit to the data

\section{Conclusions}

The results suggest that gender differences in UK academia are broadly consistent with the people/things theory. This theory was directly tested for in the current paper in preference to the communal/agentic goals theory because the latter theory is difficult to test on a large scale because goals underlying choices are typically implicit. Nevertheless, as argued above, the two theories may largely overlap, and the communal/agentic goals theory seems to explain areas where the people/things theory is not a good match to the data. Thus, the communal/agentic goals theory seems to be a better fit to the data, and this is taken into account in the following recommendations.

The additional information provided by this article that might inform initiatives to reduce STEM gender disparities relate to (a) the extent to which methods and topics are currently gendered and (b) the importance of people-orientations or communal goals for attracting female researchers. STEM initiatives might benefit from attempting to attract women to currently masculine topics and approaches, such as abstraction and mathematical quantitative methods, by promoting them to girls at school in a manner that emphasises their people-related aspects and communal goal affordances. Within academia, senior researchers may seek opportunities to promote female-friendly topics, methods, and approaches and support people-orientations or communal goals within male-dominated fields to increase recruitment and 
support retention. These field specific steps are needed in addition to paying careful attention to generic strategies for the recruitment and retention of female staff, such as by eradicating sexism, avoiding sources of unintentional bias and providing a supportive working environment. Taken together, these may help to ensure that no field is disadvantaged by a lack of female researchers.

\section{References}

Alesina, Alberto; Giuliano, Paola; Nunn, Nathan (2013). "On the origins of gender roles: Women and the plough". The quarterly journal of economics, v. 128, n. 2, pp. 469-530.

https://doi.org/10.1093/qje/qjt005

Armstrong, Mary; Jovanovic, Jasna (2017). "The intersectional matrix: Rethinking institutional change for URM women in STEM". Journal of diversity in higher education, v. 10, n. 3, pp. 216-231.

https://doi.org/10.1037/dhe0000021

Barnard, Sarah (2017). "The Athena SWAN charter: promoting commitment to gender equality in higher education institutions in the UK". In: White, Kate; O'Connor, Pat. Gendered success in higher education. London: Palgrave Macmillan UK, 2017, pp. 155-174. ISBN: 9781137566591

https://doi.org/10.1057/978-1-137-56659-1_8

Benjamini, Yoav; Hochberg, Yosef (1995). "Controlling the false discovery rate: a practical and powerful approach to multiple testing". Journal of the Royal Statistical Society. Series B (Methodological), v. 57, n. 1, pp. 289-300.

https://doi.org/10.1111/j.2517-6161.1995.tb02031.x

Brown, Lorraine; Watson, Pamela (2010). "Understanding the experiences of female doctoral students”. Journal of further and higher education, v. 34, n. 3, pp. 385-404.

https://doi.org/10.1080/0309877X.2010.484056

Bryant, Louise; Burkinshaw, Paula; House, Allan; West, Robert; Ward, Vicky (2017). “Good practice or positive action? Using Q methodology to identify competing views on improving gender equality in academic medicine". BMJ open, v. 7, n. 8, e015973. https://doi.org/10.1136/bmjopen-2017-015973

BSA (2018). Gender roles / Attitudes to gender roles: change over time?

http://www.bsa.natcen.ac.uk/latest-report/british-social-attitudes-30/gender-roles/attitudes-to-gender-roles-changeover-time.aspx

Caffrey, Louise; Wyatt, David; Fudge, Nina; Mattingley, Helena; Williamson, Catherine; McKevitt, Christopher (2016). "Gender equity programmes in academic medicine: a realist evaluation approach to Athena SWAN processes". BMJ open, v. 6, n. 9, e012090.

https://doi.org/10.1136/bmjopen-2016-012090

Cameron, Elissa; White, Angela; Gray, Meeghan (2016). "Solving the productivity and impact puzzle: do men outperform women, or are metrics biased?". BioScience, v. 66, n. 3, pp. 245-252.

https://doi.org/10.1093/biosci/biv173

Ceci, Stephen; Ginther, Donna; Kahn, Shulamit; Williams, Wendy (2014). "Women in academic science: A changing landscape". Psychological science in the public interest, v. 15, n. 3, pp. 75-141.

https://doi.org/10.1177/1529100614541236

Ceci, Stephen; Williams, Wendy (2011). "Understanding current causes of women's underrepresentation in science". Proceedings of the National Academy of Sciences, v. 108, n. 8, pp. 3157-3162.

https://doi.org/10.1073/pnas.1014871108

Chang, Lei (1999). “Gender role egalitarian attitudes in Beijing, Hong Kong, Florida, and Michigan”. Journal of cross-cultural psychology, v. 30, n. 6, pp. 722-741.

https://doi.org/10.1177/0022022199030006004

Cheryan, Sapna; Drury, Benjamin; Vichayapai, Marissa (2013). "Enduring influence of stereotypical computer science role models on women's academic aspirations". Psychology of women quarterly, v. 37, n. 1, pp. 72-79.

https://doi.org/10.1177/0361684312459328

Cheryan, Sapna; Siy, John-Oliver; Vichayapai, Marissa; Drury, Benjamin J.; Kim, Saenam (2011). "Do female and male role models who embody STEM stereotypes hinder women's anticipated success in STEM?". Social psychological and personality science, v. 2, n. 6, pp. 656-664.

https://doi.org/10.1177/1948550611405218

Cheryan, Sapna; Ziegler, Sianna; Montoya, Amanda; Jiang, Lily (2017). “Why are some STEM fields more gender balanced than others?". Psychological bulletin, v. 143, n. 1, pp. 1-35.

https://doi.org/10.1037/bul0000052 
Christensen, Martin (2017). "Men in nursing: The early years". Journal of nursing education and practice, v. 7, n. 5, pp. 94-103.

https://doi.org/10.5430/jnep.v7n5p94

Dahlberg, Lena; Demack, Sean; Bambra, Clare (2007). "Age and gender of informal carers: a population-based study in the UK". Health \& social care in the community, v. 15, n. 5, pp. 439-445.

https://doi.org/10.1111/j.1365-2524.2007.00702.x

Diekman, Amanda; Brown, Elizabeth; Johnston, Amanda; Clark, Emily (2010). "Seeking congruity between goals and roles: A new look at why women opt out of science, technology, engineering, and mathematics careers". Psychological science, v. 21, n. 8, pp. 1051-1057.

https://doi.org/10.1177/0956797610377342

Diekman, Amanda; Steinberg, Mia (2013). "Navigating social roles in pursuit of important goals: A communal goal congruity account of STEM pursuits". Social and personality psychology compass, v. 7, n. 7, pp. 487-501.

https://doi.org/10.1111/spc3.12042

Diekman, Amanda; Steinberg, Mia; Brown, Elizabeth; Belanger, Aimee; Clark, Emily (2017). "A goal congruity model of role entry, engagement, and exit: Understanding communal goal processes in STEM gender gaps". Personality and social psychology review, v. 21, n. 2, pp. 142-175.

https://doi.org/10.1177/1088868316642141

Dyer, Sarah; Walkington, Helen; Williams, Rebecca; Morton, Katherine; Wyse, Stephanie (2016). "Shifting landscapes: from coalface to quick sand? Teaching geography, earth and environmental sciences in higher education". Area, v. 48, n. 3, pp. 308-316.

https://doi.org/10.1111/area.12261

England, Paula (2010). "The gender revolution: Uneven and stalled". Gender \& society, v. 24, n. 2, pp. 149-166. https://doi.org/10.1177/0891243210361475

Etzkowitz, Henry; Kemelgor, Carol; Uzzi, Brian (2000). "Athena unbound: The advancement of women in science and technology". BioScience, v. 51, n. 6, pp. 504-509.

https://doi.org/10.1641/0006-3568(2001)051[0504:AUTAOW]2.0.CO;2

Eurostat (2019). Women in science and technology.

https://ec.europa.eu/eurostat/web/products-eurostat-news/-/EDN-20190211-1

Glass, Jennifer; Sassler, Sharon; Levitte, Yael; Michelmore, Katherine (2013). "What's so special about STEM? A comparison of women's retention in STEM and professional occupations". Social forces, v. 92, n. 2, pp. 723-756.

https://doi.org/10.1093/sf/sot092

Gordon, Allegra; Krieger, Nancy; Okechukwu, Cassandra; Haneuse, Sebastien; Samnaliev, Mihail; Charlton, Brittany; Austin, Bryn (2017). "Decrements in health-related quality of life associated with gender nonconformity among US adolescents and young adults". Quality of life research, v. 26, n. 8, pp. 2129-2138.

https://doi.org/10.1007/s11136-017-1545-1

Gregory-Smith, Ian (2018). "Positive action towards gender equality: Evidence from the Athena SWAN Charter in UK medical schools". British journal of industrial relations, v. 56, n. 3, pp. 463-483.

https://doi.org/10.1111/bjir.12252

Guarino, Cassandra; Borden, Victor (2017). "Faculty service loads and gender: Are women taking care of the academic family?". Research in higher education, v. 58, n. 6, pp. 672-694.

https://doi.org/10.1007/s11162-017-9454-2

Haeri, Shahla (2013). "No end in sight: politics, paradox, and gender policies in Iran”. Boston University law review, v. 93, pp. 1049-1062.

http://www.bu.edu/bulawreview/files/2013/08/HAERI.pdf

HESA (2018a). Data and analysis.

https://www.hesa.ac.uk/data-and-analysis

HESA (2018b). Staff in higher education 2016/17.

https://www.hesa.ac.uk/data-and-analysis/publications/staff-2016-17

HESA (2018c). Higher education student statistics: UK, 2016/17 - Qualifications achieved.

https://www.hesa.ac.uk/news/11-01-2018/sfr247-higher-education-student-statistics/qualifications

HESA (2018d). Academic staff by cost centres.

https://www.hesa.ac.uk/data-and-analysis/staff/cost-centres 
HESA (2019). HE academic staff by nationality and cost centre. https://www.hesa.ac.uk/data-and-analysis/staff/areas (2017/8 data)

Hines, Melissa (2011). "Gender development and the human brain". Annual review of neuroscience, v. 34, pp. 69-88. https://doi.org/10.1146/annurev-neuro-061010-113654

Holman, Luke; Stuart-Fox, Devi; Hauser, Cindy (2018). "The gender gap in science: How long until women are equally represented?". PLoS biology, v. 16, n. 4, e2004956.

https://doi.org/10.1371/journal.pbio.2004956

Kandiko-Howson, Camille; Coate, Kelly; De-St-Croix, Tania (2018). "Mid-career academic women and the prestige economy". Higher education research \& development, v. 37, n. 3, pp. 533-548.

https://doi.org/10.1080/07294360.2017.1411337

Larivière, Vincent; Desrochers, Nadine; Macaluso, Benoit; Mongeon, Philippe; Paul-Hus, Adele; Sugimoto, Cassidy (2016). "Contributorship and division of labor in knowledge production". Social studies of science, v. 46, n. 3, pp. 417435. https://doi.org/10.1177/0306312716650046

Lindsey, Linda (2016). Gender roles: A sociological perspective. London: Routledge. ISBN: 9781317348078 https://doi.org/10.4324/9781315664095

Lipton, Briony (2017). “Measures of success: cruel optimism and the paradox of academic women's participation in Australian higher education". Higher education research \& development, v. 36, n. 3, pp. 486-497. https://doi.org/10.1080/07294360.2017.1290053

Maddrell, Avril; Strauss, Kendra; Thomas, Nicola; Wyse, Stephanie (2016). “Mind the gap: Gender disparities still to be addressed in UK higher education geography". Area, v. 48, n. 1, pp. 48-56.

https://doi.org/10.1111/area.12223

Main, Joyce (2018). "Kanter's theory of proportions: Organizational demography and PhD completion in science and engineering departments". Research in higher education, v. 59, n. 8, pp. 1059-1073.

https://doi.org/10.1007/s11162-018-9499-x

Mehran, Golnar (2009). “'Doing and undoing gender': Female higher education in the Islamic Republic of Iran”. International review of education, v. 55, n. 5/6, pp. 541-559.

https://doi.org/10.1007/s11159-009-9145-0

Moss-Racusin, Corinne; Dovidio, John; Brescoll, Victoria; Graham, Mark; Handelsman, Jo (2012). "Science faculty's subtle gender biases favor male students". Proceedings of the National Academy of Sciences, v. 109, n. 41, pp. 1647416479. https://doi.org/10.1073/pnas.1211286109

Mott, Jason; Lee, Danny (2018). "Navigating unfamiliar waters: Men in nursing academia”. Journal of professional nursing, v. 34, n. 1, pp. 42-46.

https://doi.org/10.1016/j.profnurs.2017.07.005

Nielsen, Mathias (2016). "Gender inequality and research performance: moving beyond individual-meritocratic explanations of academic advancement". Studies in higher education, v. 41, n. 11, pp. 2044-2060. https://doi.org/10.1080/03075079.2015.1007945

Nunkoo, Robin; Thelwall, Mike; Ladsawut, Jeynakshi; Goolaup, Sandhiya (2020). "Three decades of tourism scholarship: Gender, collaboration and research methods". Tourism management, v. 78, article 104056.

https://doi.org/10.1016/j.tourman.2019.104056

Office for National Statistics (2013). The gender gap in unpaid care provision: is there an impact on health and economic position? https://bit.ly/2WmAv00

Othman, Mazliza; Latih, Rodziah (2006). "Women in computer science: no shortage here!". Communications of the ACM, v. 49, n. 3, pp. 111-114. https://doi.org/10.1145/1118178.1118185

Ovseiko, Pavel; Chapple, Alison; Edmunds, Laurel; Ziebland, Sue (2017). "Advancing gender equality through the Athena SWAN Charter for Women in Science: an exploratory study of women's and men's perceptions". Health research policy and systems, v. 15, n. 1, article 12.

https://doi.org/10.1186/s12961-017-0177-9 
Reuben, Ernesto; Sapienza, Paola; Zingales, Luigi (2014). "How stereotypes impair women's careers in science”. Proceedings of the National Academy of Sciences, v. 111, n. 12, pp. 4403-4408. https://doi.org/10.1073/pnas.1314788111

Rippon, Gina (2019). The Gendered Brain: The new neuroscience that shatters the myth of the female brain. Random House. ISBN: 9781847924766

Robnett, Rachel (2016). "Gender bias in STEM fields: Variation in prevalence and links to STEM self-concept". Psychology of women quarterly, v. 40, n. 1, pp. 65-79.

https://doi.org/10.1177/0361684315596162

Rørstad, Kristoffer; Aksnes, Dag (2015). "Publication rate expressed by age, gender and academic position - A large-scale analysis of Norwegian academic staff". Journal of informetrics, v. 9, n. 2, pp. 317-333.

https://doi.org/10.1016/j.joi.2015.02.003

Rosser, Sue; Barnard, Sarah; Carnes, Molly; Munir, Fehmidah (2019). "Athena Swan and Advance: effectiveness and lessons learned". The lancet, v. 393, n. 10171, pp. 604-608.

https://doi.org/10.1016/S0140-6736(18)33213-6

Sassler, Sharon; Glass, Jennifer; Levitte, Yael; Michelmore, Katherine (2017). "The missing women in STEM? Assessing gender differentials in the factors associated with transition to first jobs". Social science research, v. 63, pp. $192-208$. https://doi.org/10.1016/j.ssresearch.2016.09.014

Schucan-Bird, Karen (2011). "Do women publish fewer journal articles than men? Sex differences in publication productivity in the social sciences". British journal of sociology of education, v. 32, n. 6, pp. 921-937.

https://doi.org/10.1080/01425692.2011.596387

Scopus (2018). How Scopus works - content.

https://www.elsevier.com/solutions/scopus/how-scopus-works/content

Shapiro, Jenessa; Williams, Amy (2012). “The role of stereotype threats in undermining girls' and women's performance and interest in STEM fields". Sex roles, v. 66, n. 3-4, pp. 175-183.

https://doi.org/10.1007/s11199-011-0051-0

Shavarini, Meredith (2005). "The feminisation of Iranian higher education". International review of education, v. 51, n. 4, pp. 329-347. https://doi.org/10.1007/s11159-005-7738-9

Sheltzer, Jason; Smith, Joan (2014). "Elite male faculty in the life sciences employ fewer women". Proceedings of the National Academy of Sciences, v. 111, n. 28, pp. 10107-10112.

https://doi.org/10.1073/pnas.1403334111

Sherer, Michael; Zakaria, Idlan (2018). "Mind that gap! An investigation of gender imbalance on the governing bodies of UK universities". Studies in higher education, v. 43, n. 4, pp. 719-736.

https://doi.org/10.1080/03075079.2016.1196352

Society of Biology (2013). Women in academic STEM careers.

https://www.rsb.org.uk/images/Society_of_Biology_response_to_women_in_STEM_careers_inquiry.pdf

Stockard, Jean; Greene, Jessica; Richmond, Geraldine; Lewis, Priscilla (2018). "Is the gender climate in chemistry still chilly? Changes in the last decade and the long-term impact of COACh-sponsored workshops". Journal of chemical education, v. 95, n. 9, pp. 1492-1499.

https://doi.org/10.1021/acs.jchemed.8b00221

Stoet, Gijsbert; Geary, David (2018). "The gender-equality paradox in science, technology, engineering, and mathematics education". Psychological science, v. 29, n. 4, pp. 581-593.

https://doi.org/10.1177/0956797617741719

Su, Rong; Rounds, James (2015). "All STEM fields are not created equal: People and things interests explain gender disparities across STEM fields". Frontiers in psychology, v. 6, n. 189.

https://doi.org/10.3389/fpsyg.2015.00189

Su, Rong; Rounds, James; Armstrong, Patrick (2009). "Men and things, women and people: A meta-analysis of sex differences in interests". Psychological bulletin, v. 135, n. 6, pp. 859-884.

https://doi.org/10.1037/a0017364

Tellhed, Una; Bäckström, Martin; Björklund, Fredrik (2017). "Will I fit in and do well? The importance of social belongingness and self-efficacy for explaining gender differences in interest in STEM and HEED majors". Sex roles, v. 77, n. 1-2, pp. 86-96.

https://doi.org/10.1007/s11199-016-0694-y 
Tenreyro, Silvana (2017). Royal Economic Society's report on the gender balance in UK economics departments and research institutes in 2016.

http://personal.Ise.ac.uk/tenreyro/women.pdf

Thelwall, Mike; Bailey, Carol; Makita, Meiko; Sud, Pardeep; Madalli, Devika (2019). "Gender and research publishing in India: Uniformly high inequality?". Journal of informetrics, v. 13, n. 1, pp. 118-131.

https://doi.org/10.1016/j.joi.2018.12.003

Thelwall, Mike; Bailey, Carol; Tobin, Catherine; Bradshaw, Noel-Ann (2019). "Gender differences in research areas, methods and topics: Can people and thing orientations explain the results?". Journal of informetrics, v. 13, n. 1, pp. 149-169. https://doi.org/10.1016/j.joi.2018.12.002

UNDP (2016). Human development report 2016: Human development for everyone. http://hdr.undp.org/sites/default/files/hdr_2016_statistical_annex.pdf

US Department of Labor (2019). Postsecondary teachers.

https://www.bls.gov/ooh/education-training-and-library/postsecondary-teachers.htm\#tab-7

Van-Arensbergen, Pleun; Van-der-Weijden, Inge; Van-den-Besselaar, Peter (2012). "Gender differences in scientific productivity: a persisting phenomenon?". Scientometrics, v. 93, n. 3, pp. 857-868.

https://doi.org/10.1007/s11192-012-0712-y

Van-den-Brink, Marieke; Benschop, Yvonne (2012). "Gender practices in the construction of academic excellence: Sheep with five legs". Organization, v. 19, n. 4, pp. 507-524.

https://doi.org/10.1177/1350508411414293

Wang, Qi; Waltman, Ludo (2016). "Large-scale analysis of the accuracy of the journal classification systems of Web of Science and Scopus". Journal of informetrics, v. 10, n. 2, pp. 347-364.

https://doi.org/10.1016/j.joi.2016.02.003

Watson, Catie (2019). "How much do U.S. professors earn?". The Chron. https://work.chron.com/much-professors-earn-8913.html

Welton, Tom (2016). "Building an inclusive culture in the Chemistry Department at Imperial College". Chemistry - A European journal, v. 22, n. 11, pp. 3535-3536.

https://doi.org/10.1002/chem.201600475

Williams, Elizabeth; Kolek, Ethan; Saunders, Daniel; Remaly, Alicia; Wells, Ryan (2018). "Mirror on the field: Gender, authorship, and research methods in higher education's leading journals". The journal of higher education, v. 89, n. 1, pp. 28-53.

https://doi.org/10.1080/00221546.2017.1330599

Williams, Wendy; Ceci, Stephen (2015). "National hiring experiments reveal 2:1 faculty preference for women on STEM tenure track". Proceedings of the National Academy of Sciences, v. 112, n. 17, pp. 5360-5365.

https://doi.org/10.1073/pnas.1418878112

Wright, Hazel; Cooper, Linda; Luff, Paulette (2017). "Women's ways of working: Circumventing the masculine structures operating within and upon the University". Women's studies international forum, v. 61, n. 2, pp. $123-131$.

https://doi.org/10.1016/j.wsif.2016.11.006

Xie, Yu; Shauman, Kimberlee (1998). "Sex differences in research productivity: New evidence about an old puzzle". American sociological review, v. 63, n. 6, pp. 847-870.

https://doi.org/10.2307/2657505

Yang, Yang; Barth, Joan (2015). “Gender differences in STEM undergraduates' vocational interests: People-thing orientation and goal affordances". Journal of vocational behavior, v. 91, n. 1, pp. 65-75.

https://doi.org/10.1016/j.jvb.2015.09.007

Young, Danielle; Rudman, Laurie; Buettner, Helen; McLean, Meghan (2013). "The influence of female role models on women's implicit science cognitions". Psychology of women quarterly, v. 37, n. 3, pp. 283-292.

https://doi.org/10.1177/0361684313482109 